\title{
scripted
}

Volume 8, Issue 3, December 2011

\section{Challenges for Free ACCess to LaW in a Multi- JURISDICTIONAL DEVELOPING COUNTRY: BUILDING THE LEGAL INFORMATION INSTITUTE OF INDIA}

\author{
Graham Greenleaf, VC Vivekanandan, Philip Chung, Ranbir Singh and Andrew \\ Mowbray
}

\begin{abstract}
This article analyses the complexities involved in providing free public online access to the "public legal information" of the Indian legal system. It starts with some of the causes of the complexity of Indian legal information then describes the considerable progress that has previously been made in the provision of free access to some types of legal information, but why the result is still below international standards. The article then explains a project to remedy some of these deficiencies, the Legal Information Institute of India (LII of India), being carried out by eight Indian law schools and an international partner. It has developed in its first year of public operation, the LII of India, a system with over 750,000 searchable documents and 151 databases. The considerable remaining challenges for creation of a world-standard and sustainable system are then outlined, and steps proposed to address them. The extent to which this collaborative project might be a model for development of free access to legal information in other countries is considered.
\end{abstract}

\footnotetext{
* Graham Greenleaf, Professor of Law \& Information Systems, University of New South Wales; Dr VC Vivekanandan, Ministry of HRD IP Chair Professor, NALSAR University of Law, Hyderabad; Philip Chung, Lecturer in Law, University of Technology, Sydney and Conjoint Lecturer in Law, UNSW; Prof (Dr) Ranbir Singh, Vice-Chancellor, National Law University, Delhi; Andrew Mowbray, Professor of Law \& Computer Science at the University of Technology, Sydney. The assistance of Rajan Sharma, system developer for LII of India at AustLII, Jill Matthews, Indexer, prior AustLII staff, and SCRIPTed editors and referees is gratefully acknowledged. An earlier version of this article was presented at the Law via the Internet Conference, University of Hong Kong, 2011, and the article was completed while Graham Greenleaf was a Visiting Fellow at the SCRIPT/AHRC Law and Technology Centre, University of Edinburgh. The LII of India has been assisted by an AusAID Public Sector Linkages Program (PSLP) grant concerning access to South Asian legal information, and from an Australian Research Council (ARC) LIEF grant concerning CommonLII.
} 
By "public legal information" we mean that information which, as a matter of public policy, ought to be available for free public access in a society which values democracy and the rule of law. This has been argued elsewhere to include legislation, case law, treaties a country has entered into, reports proposing reform of the law, and such legal scholarship as authors have chosen or are required to make freely available to the public. ${ }^{1}$ For the purpose of this article, this definition is assumed.

DOI: $10.2966 /$ scrip.080311.292

\section{(c) (i) $\odot$}

(c) Graham Greenleaf, VC Vivekanandan, Philip Chung, Ranbir Singh and Andrew Mowbray 2011. This work is licensed under a Creative Commons Licence. Please click on the link to read the terms and conditions.

\footnotetext{
${ }^{1}$ The main source of this formula is Free Access to Law Movement Declaration on Free Access to Law, Montreal, 2002, as amended, at $<$ http://www.fatlm.org/declaration/ $>$; for background see $G$ Greenleaf, "Free Access to Legal Information, LIIs, and the Free Access to Law Movement", in R Danner and $\mathrm{J}$ Winterton (eds), IALL International Handbook of Legal Information Management $\begin{array}{lll}\text { (Aldershot, } \quad \text { Burlington } & \text { VT: } & \text { Ashgate, } \\ <\text { http://papers.ssrn.com/sol3/papers.cfm?abstract id=1960867>. }\end{array}$
} 


\section{The Complexity of the Indian Legal and Social Contexts}

Developing a free access legal information system for India involves more complex technical and organisational issues than is the case for most other countries. This is because of the complexity of India's constitutional structure and resulting legal institutions, the value it places on democracy, human rights and the rule of law, the litigious nature of its citizens, its linguistic complexity, and its expanding market economy.

\subsection{A Complex, Sophisticated Legal System and a Litigious Society}

India is a very complex country of thirty-six jurisdictions: the Union, twenty-eight states and seven Union Territories comprise a system which shares characteristics of both a federation and (because of the powers of the centre) a unitary government. ${ }^{2}$ It is a parliamentary democracy with a written constitution including human rights provisions. ${ }^{3}$ The constitution is constantly interpreted by an activist Supreme Court which has delivered over 29,000 decisions since 1950 , a rate of 500 per year. ${ }^{4}$ Since independence from the United Kingdom in 1947, India has gradually expanded its number of states and territories through splitting existing states, primarily on linguistic lines, ${ }^{5}$ and the process continues. This means there has been a steady increase in the number of separate legislatures, and the number of high courts (the apex court within a state), although some states and territories still share a high court.

India's judicial system is primarily based on the common law tradition inherited from English law, with decisions of Indian courts going back to the eighteenth century. Its judicial structure is that of a "single structure of courts with the Supreme Court at its apex". Central government legislation which is still in force dates from 1857, and that of some states goes back even earlier (for example, West Bengal to at least 1848). ${ }^{7}$ The complexity of Indian law is therefore both broad and deep. The number of court decisions by Indian courts is prodigious compared with most countries. The total number of published decisions of India's Supreme Court and high courts approaches three quarters of a million for the past decade alone. Unlike some countries in Asia, India can be considered to be a litigious country in which people at all levels of life resort to the Courts to resolve many disputes (even though this often takes many years). Judicial and quasi-judicial forms have also gone beyond those based on British or common law models. The first local people's courts, or lok adalats was established in Chennai in 1986, based on Article 31A of the Constitution, and have gradually widened their scope from matrimonial affairs into many other

\footnotetext{
${ }^{2}$ B Chandra, M Mukherjee and A Mukherjee, India since Independence (New Delhi: Penguin, 2008), at $62-5$.

${ }^{3}$ Ibid, ch 2 .

${ }^{4}$ See http://www.liiofindia.org/in/cases/cen/INSC/.

${ }^{5}$ B Chandra, M Mukherjee and A Mukherjee, see note 2 above, ch 8.

${ }^{6} \mathrm{Ibid}$, at $77-80$.

${ }^{7}$ http://www.liiofindia.org/in/legis/wb/act/
} 
matters. $^{8}$ Numerous administrative tribunals have been established ${ }^{9}$ which are relatively more accessible to ordinary people than many courts, including tribunals for electricity and railway disputes. Some of these tribunals report considered decisions (as distinct from merely deciding cases) in vast numbers. There are 67,651 reported decisions interpreting the RTI Acts from the Central Information Commission of India from 2006-2011, ${ }^{10}$ an average of more than 10,000 decisions per year.

\subsection{A "Monitory Democracy"}

Indian democracy has twice recovered from near-death experiences, in 1975 to 1977 and in 2002 to $2004 .{ }^{11}$ It was brought back to life by the Indian people at the ballot box. Indian democracy is vibrant and tumultuous, despite its vicissitudes, the most obvious at present being the prevalence of corruption and the strong campaigns against it. Representative democracy goes beyond central and state legislatures, with local self-government (panchayats) having been introduced into India's 600,000 villages and towns in $1993^{12}$. Keane argues that developments in Indian democracy are the clearest example of a new form of democracy that he calls "monitory democracy"," distinct from direct democracy and representative democracy, that has emerged since the Second World War (coincident with Indian independence since 1947). He argues that India shows more clearly than elsewhere a recognition that citizens' interests in a democracy "must be represented not just through elections and debates and decisions in the central parliament, but in a wide range of post-Westminster processes", the essence of which is that they are "new mechanisms designed to introduce greater public accountability in the making of decisions by government". Among the devices he notes are the panchayats, very strong judicial review, compulsory quotas for those not previously represented in politics, and constitutional protection of indigenous rights. ${ }^{14}$

And of vital importance was the application of new power-checking mechanisms, including lok adalats and water consultation schemes, but also extra-parliamentary inventions like participatory budgeting; "yellow card" reports on government services issued by citizen groups; the handling of public disputes through railway courts... and the invention of public interest litigation... enabling individuals and groups ... to have

\footnotetext{
${ }^{8}$ J Keane, The Life and Death of Democracy (London: Pocket Books, 2010), at 622-623.

${ }^{9}$ See a list of fifteen such tribunals at http://www.worldlii.org/catalog/56666.html.

${ }^{10}$ See http://www.liiofindia.org/in/cases/cen/INCIComm/.

${ }^{11}$ The autocracy of the Emergency of 1975 to 1977 and communalism of 2002 to 2004. See B Chandra, M Mukherjee, and A Mukherjee, see note 2 above at chs 18 and 36 and J Keane, see note 8 above, at 618-619 and 637-647.

$12 \mathrm{~J}$ Keane, see note 8 above, at 627.

${ }^{13}$ Keane notes that a similar term, "monitorial democracy" has been used by US scholar Michael Schudson, who has influenced his approach. See J Keane, see note 8 above, at 688 in footnote. Keane also uses the term "banyan democracy" in relation to India, showing why the banyan tree is a very appropriate metaphor for the features of monitory democracy. Ibid, 630-631. But to a lawyer, "banyan democracy" is too close to the dismissive phrase "palm tree justice" to have positive connotations.

${ }^{14}$ Ibid, 629-630.
} 
their grievances presented on their behalf to the courts by public spirited individuals, or by the courts themselves. ${ }^{15}$

Monitory inventiveness continues since Keane wrote, notably including the "I Paid a Bribe" online whistle-blowing movement, ${ }^{16}$ which aims to "uncover the market price of corruption" and invites readers to "tell us your bribe story", so that de-identified information can produce maps of India's bribery "hot spots" down to the level of individual departments and cumulative amounts of bribes paid.

Of the wide range of mechanisms of "monitory democracy" India has developed, one of the most striking (though not noted by Keane) and most relevant to free access to legal information, is the development of the right to information.

\subsection{Constitutional Right to Information and Bureaucratic Lag}

India has developed a constitutional right to public information. A number of Indian states enacted "right to information" (RTI) Acts from 1997 to 2004, ${ }^{17}$ covering what is elsewhere called "freedom of information" in relation to the public sector. In 2004 India's Supreme Court conclusively interpreted Article 19(1)(a) of the Constitution of India to impliedly include the right to information in the constitutional guarantees of freedom of speech and expression (People's Union for Civil Liberties $v$ Union of India). ${ }^{18}$ Consequently, national legislation was enacted as the Right to Information Act 2005. The reach of the legislation applies to all tiers of government and considerably beyond that to some parts of the private sector. This right, forced on the national government by the Supreme Court, has resulted in Indian government institutions being required to make new efforts towards data management, and to provide access to the community about the laws that govern them.

Though the constitutional right of freedom of speech has been interpreted to include access to information, this constitutional principle has not yet been developed in relation to legal information to require governments to meet the needs of the ordinary citizen to access legal information for free or to international standards of quality. One possible opportunity for the free access to law movement in India, which would rarely be possible in other countries, is to trigger a constitutional action to extend the scope of the constitutional guarantees toward a positive requirement to provide effective public access to legal information. Even if unsuccessful in the courts, such an initiative might catch people's imagination and demonstrate the need for government to take more effective action in relation to access to legal information.

India is often praised as a successful democracy and open society ${ }^{19}$ but this is still limited when it comes to access to legal information. As we will see, information on legislation and judicial decisions is scattered and often buried in a maze of websites run by ministries at central, state and territory levels. It is ironic that, while India is a hub for outsourced data processing, with a myriad of infotech companies working to

\footnotetext{
${ }^{15}$ Ibid, 630.

${ }^{16}$ See http://ipaidabribe.com/

${ }^{17}$ Tamil Nadu, Goa, Rajasthan, Delhi, Maharashtra, Assam, Madhya Pradesh, Jammu, and Kashmir.

18 (2004) AIR 2004 SC 1442.

${ }^{19}$ See for example J Keane, see note 8 above, at 585-647.
} 
cater to the database demands of the developed world, insufficient resources have been put into India's "domestic space" to bring it up to international standards.

\section{4 "Auntie English" and the Complexity of Language Issues}

India has twenty-two official languages, and somewhere between 150 and 1,500 languages (depending on definitions of language and dialect). ${ }^{20}$ Questions of language always have been and always will be controversial in India. Many independence leaders saw Hindi as the language of colonialism. However, proposals to adopt Hindi as the only official language in the Constitution met strong resistance from India's southern states, where it was not spoken widely. It was decided that the Constitution would provide that Hindi would be India's official language, but English was to continue in use for all official purposes until 1965 when Hindi would become the sole official language. However, opposition from the south continued (and was fortified by support from the Dalit community), and in 1967 a compromise was reached providing that "the use of English as an associate language in addition to Hindi for the official work at the Centre and for communication between the Centre and the non-Hindi states would continue as long as the non-Hindi states wanted it". ${ }^{21}$

The authors of an authoritative history of India since independence note that India is now becoming more multilingual, with knowledge of Hindi spreading in the south though modern communications and entertainment and the study of English become more common in all strata of Indian society as a language of economic advancement. They conclude that "English is not only likely to survive in India for all time to come, but it remains and is likely to grow as a language of communication between the intelligentsia all over the country, as a library language, and as the second language of the universities". ${ }^{22}$ It is also likely to retain its privileged, but not exclusive, position in the legal system for some time to come. ${ }^{23}$ One of the founders of Infosys, India's first successful high technology company recounts that "the seven founders of Infosys between themselves spoke five different languages at home, and English was the only language we shared". ${ }^{24}$

Estimates of the current percentage of English-speakers in India vary. It may be as high as $11 \%{ }^{25}$ The exact percentage is not important, but it is important to note that most sources of legal information in India are in English, a language that is only directly accessible by a minority of the population. The majority must otherwise rely on English-speaking intermediaries to deal with the legal system, at least at its higher levels. Nevertheless, English is the "link language" between all geographical and linguistic areas of the country, and the most common language of administration,

\footnotetext{
${ }^{20} \mathrm{~N}$ Nilekani, Imagining India: Ideas for a New Century (London: Allen Lane, 2008), at 77, and see generally 77-94.

${ }^{21}$ B Chandra, M Mukherjee and A Mukherjee, see note 2 above, at 123; and see generally 113-124; see also N Nilekani, note 20 above, at 77-85.

${ }^{22}$ B Chandra, M Mukherjee and A Mukherjee, see note 2 above, at 124.

${ }^{23}$ Discussed in more detail below at "Languages Other than English".

${ }^{24} \mathrm{~N}$ Nilekani, see note 20 above, at 77.

25 Wikipedia article "List of Countries by English-Speaking Population" at http://en.wikipedia.org/wiki/List_of_countries_by_English-speaking_population.
} 
business and the law. Nilekani calls it India's "auntie" language - perhaps not exactly one of the family, but still a welcome guest.

\subsection{The Need for Free Access to Indian Legal Information}

When considering needs, we should consider the various audiences that a free access legal information system for India could attempt to serve. At a minimum, the legal profession, government administrators, small to medium businesses (SMEs), NGOs, students and academics, and the general public, can all be considered as somewhat distinct audiences who may value such a service.

As is the case in many developing countries, a high quality free access legal information system can have considerable significance for the legal profession, because the majority of lawyers do not have access to the commercial online services for legal information provided by the multinational legal publishers and a small number of Indian commercial providers. Nor do SMEs, NGOs, students and academics, also all potentially significant categories of users. Only a minority of them will be able to afford the cost of accessing most commercial online services. Nevertheless, all of them need to make considerable use of legal resources. Existing resources available for free access from government have serious limitations (discussed in the next section). By and large, these categories of users will be able to cope with the language requirements of a legal system which operates primarily in English, and they will be able to obtain a basic level of Internet access necessary to make use of such a service.

The extent to which such a free access service can be made relevant to the needs of the general public in India (and in most developing countries) is a different and more difficult question because of great differences in levels of Internet access, and literacy (particularly in relation to a legal system which still operates largely in English).

\section{The State of Access to Indian Legal Information to 2010}

One aspect of the difficulties of developing a free access legal information system for India can be seen by considering each category of legal information that other LIIs often include, and that we consider to be the "five pillars" of free access to law: legislation, case law, treaties, law reform and open scholarship.

\subsection{Legislation}

Legislation from the Central government is in theory available online from the "India Code" database ${ }^{26}$ provided by India's National Informatics Centre (NIC). The problem is that the NIC database has not included consolidations of acts for many years (consistent consolidation seems to have stopped in the 1990s), and to make matters worse many amending acts are not included either. Central government delegated legislation is only available from departmental websites, if at all. In the

\footnotetext{
${ }^{26}$ India Code http://indiacode.nic.in/. See the "About the India Code" page which implies that the legislation found there is "available in up-to-date form", when this is not so. The Acts have not been consolidated for some years, although they were originally when the service was established in the mid-1990s.
} 
states and territories the government offices responsible for legislation only intermittently produce consolidations of legislation, and usually years in arrears, so that this lucrative field is largely left to commercial publishers. The provision of online legislation varies greatly among states, ranging from nearly non-existent to occasionally approaching comprehensiveness of either annual or consolidated legislation. The one government site that attempts to aggregate state and territory legislation only provides a very incomplete coverage because its sources share the defects previously discussed. ${ }^{27}$ For the general public, most businesses and litigants, and for most lawyers other than the wealthiest, up-to-date legislation can only be obtained from small publishers in pamphlet form, often sold through outlets such as those shown below.

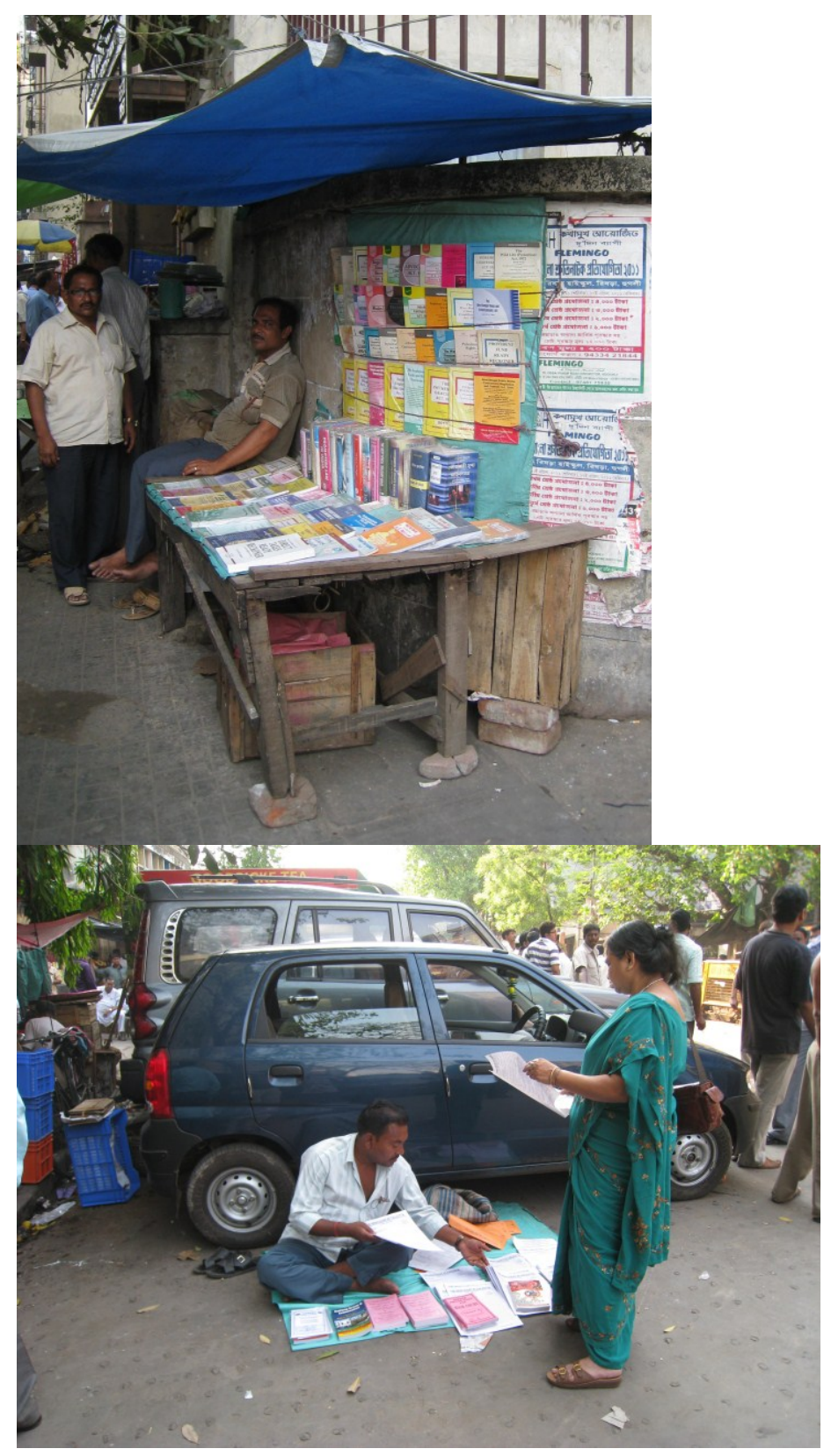

27 On the India.Gov site, see the Acts http://india.gov.in/govt/acts.php and Rules \& Regulations http://india.gov.in/govt/rules.php pages. 


\section{Two Legislation Vendors in the Street behind the High Court of Kolkota, April 2011}

\subsection{Case Law}

Case law has been provided online, usually for about ten years, by a series of NICdeveloped databases for the Supreme Court, twenty-four high courts, six district courts, and most of the larger central government tribunals. Although all of the databases are presented through one central website, the Judgment Information System (JUDIS), ${ }^{28}$ there is no overall search facility. On the one hand this has been a heroic effort, with somewhere between half a million to a million cases being provided for free access. However, it has crippling limitations for serious legal research because of the following factors: (i) the data is spread over more than thirty completely separate databases in different locations, all with search-based interfaces that are different from each of the other court interfaces; (ii) the interfaces are largely impenetrable unless users already know which case they want to find; and (iii) the contents of the databases cannot be browsed, because there are not tables of contents.

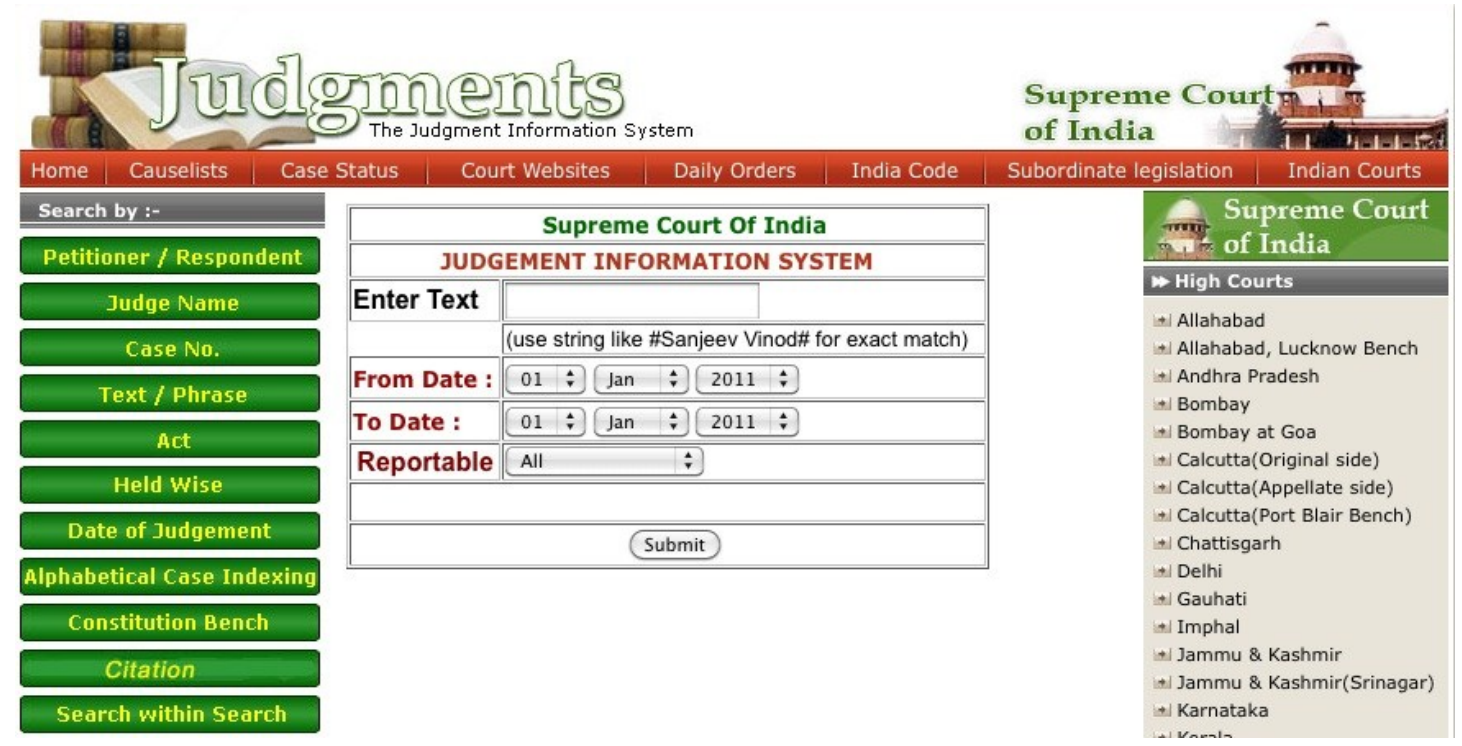

\section{One of Eleven Possible Search Screens in the NIC/JUDIS Interface to Supreme Court Decisions}

The rather inflexible text search interface for the Supreme Court is shown above. India-wide searching for case law is therefore impossible using these government resources, because each court database has to be searched separately. Even free text word searching is ineffective for most high courts. The comprehensiveness of the JUDIS databases is also an open question: they need systematic testing. ${ }^{29}$

\footnotetext{
${ }^{28}$ JUDIS at http://judis.nic.in/.

${ }^{29}$ Instances of leading cases being missing from the database have been found by the authors, but systematic testing has not yet been done.
} 


\subsection{Treaties, Scholarship and Law Reform}

India since independence has always been a very active participant in international law, but its treaties are hard to find. From 1947 to 1980 India's bilateral treaties were published by a commercial publisher in book form, and those treaties are available on the Ministry of External Affairs website ${ }^{30}$ but not searchable. Post-1980, the situation is much worse. The online availability of treaties on the Ministry website is sporadic, there is no printed compilation of bilateral treaties, and even the Ministry does not hold a consolidated set in a reproducible form. ${ }^{31}$

India has hundreds of law schools, of very varying quality. Since the formation of the National Law School of India University, Bangalore, in 1987, fourteen National Law Schools ${ }^{32}$ have been developed as "stand alone" universities across India, and former Union Law Minister Moily stated that fourteen more will be developed: "There are now 14 such schools, the idea is to have one national law school in each State". 33 With a small number of new private law schools and a handful of law schools in state universities, they constitute a "top tier" of Indian legal education (though various private law colleges are also highly ranked), and are often of high international repute. However, dedicated online sources of Indian legal scholarship are hard to find. There are no India-wide repositories of legal scholarship equivalent to the Legal Scholarship Network (LSN) on SSRN, ${ }^{34}$ or the bePress Legal Repository, ${ }^{35}$ or AustLII's Legal Scholarship Library. ${ }^{36}$ There is as yet only a scattering of Indian academic law journals on the web. Indian legal scholars generally prefer to publish in foreign law journals because of the low visibility of their own journals. One unfortunate situation is that the Indian Law Institute's Journal and Yearbook ("Annual Survey"), to which scholars from all over India have contributed for decades, ${ }^{37}$ and which are centrepieces of India legal scholarship, have allowed LexisNexis to have exclusive online rights to date. Issues of corresponding benefits to the Institute, and the authors of articles, compared with the benefits of free public access, deserve reconsideration in the emerging very different international information environment for legal scholarship.

Law reform is carried out by many bodies in India. The national Law Commission has made all thirty-six of its reports since 1950 available online, ${ }^{38}$ but few state law reform bodies do so (the Goa Law Commission, for example, is exceptional), ${ }^{39}$ and

\footnotetext{
${ }^{30}$ Ministry of External Affairs website http://www.mea.gov.in/ .

${ }^{31}$ Personal communication from a senior officer of the Ministry (Jan 2010).

32 See list of National Law Schools and links at http://www.austlii.edu.au/catalog/56662.html.

33 'Moily Inaugurates CLEA and Talks of 14 More National Law Schools', Bar \& Bench (30 Jan 2011), at http://barandbench.com/, quoting from The Hindu.

${ }^{34}$ http://www.ssrn.com/lsn/index.html.

35 http://law.bepress.com/.

36 http://www.austlii.edu.au/au/journals/.

${ }^{37}$ Indian Law Institute's publications page available at http://www.ilidelhi.org/publication.htm.

${ }^{38}$ http://lawcommissionofindia.nic.in/ .

${ }^{39}$ http://goalawcommission.gov.in/reports.htm.
} 
nor do most of the bodies tasked with a specific subject of investigation and law reform (the National Human Rights Commission is an exception). ${ }^{40}$

\subsection{The Key Deficiency: A Lack of Comprehensive Search Facilities}

In addition to the separate deficiencies of each of the existing sources of free access online resources, the over-riding problem is that no free access source have created facilities so that all of these sources - case law, central and state legislation, treaties, open access scholarship and law reform - to be searched together. There is no comprehensive site which allows users to search any one of these "five pillars" of legal information across India, let alone all five of them.

Some non-government free access providers have, however, been taking steps recently to remedy parts of these problems, notably the NGO Parliamentary Research Service (PRS) in relation to legislation, and IndianKanoon in relation to case law. Their efforts are occurring in parallel with the efforts being made by LII of India, and will be discussed later.

\section{The Building the LII of India after One Year (2011)}

We now turn to a project that attempts to build on, enhance and consolidate much of the good work that has already been done by Indian government organisations, and NGOs, to develop free access to legal information in India, and to overcome many of the deficiencies identified in the previous section.

\subsection{Background: The Free Access to Law Movement and AustLII}

For nearly twenty years various academic-based organisations, initially in the USA, Australia and Canada, have been making public legal information available for free access via the Internet, and have self-consciously done so as a group of collaborating "legal information institutes" (LIIs). ${ }^{41}$ Since 2002 they have done so as the Free Access to Law Movement (FALM), which now has over forty members, ${ }^{42}$ with an ideology expressed in the Declaration on Free Access to Law, ${ }^{43}$ based on the rights of individuals to have effective free access to public legal information, and the right of those who wish to republish that information to meet that need to be able to do so.

The Australasian Legal Information Institute (AustLII) has been at the forefront of those developments since $1995,{ }^{44}$ and operates by far the largest and most-accessed

\footnotetext{
${ }^{40}$ http://www.nhrc.nic.in/.

${ }^{41}$ See G Greenleaf, "Free access to legal information, LIIs, and the Free Access to Law Movement", in $\mathrm{R}$ Danner and J Winterton (eds), IALL International Handbook of Legal Information Management (Aldershot; Burlington $\quad$ VT: Ashgate, 2011), available at http://papers.ssrn.com/sol3/papers.cfm?abstract_id=1960867.

${ }^{42}$ See "Members of the Free Access to Law Movement (FALM)", available at http://www.fatlm.org/.

${ }^{43}$ Free Access to Law Movement, "Declaration on Free Access to Law" (2002 and subsequent amendments), available at http://www.fatlm.org/declaration/.

${ }^{44}$ See G Greenleaf, A Mowbray, and P Chung, “AustLII: Thinking locally, acting globally” (2011) Australian Law Librarian, 101-111, available as (2011) UNSWLRS 41 at http://papers.ssrn.com/sol3/papers.cfm?abstract_id=1960878. See also G Greenleaf, A Mowbray, and P
} 
online legal resource in Australasia. ${ }^{45}$ Since 2000 it has been assisting organisations in other countries to develop free access to legal information in their countries or regions, and also operating three collaborative portals for those FALM members who wish to participate, WorldLII, CommonLII and AsianLII. ${ }^{46}$

\subsection{Formation of LII of India (2007-2011)}

The LII of India has had a long gestation. In 1999 AustLII had its first discussion with a national law school in India (NLUI, Bangalore via Dr Vivekandan) about expanding free access to Indian law in the context of an Asian Development Bank Project (Project DIAL - Developing the Internet for Asian Law). These discussions were taken up again in 2007, both with (then) Vice-Chancellor Ranbir Singh of NALSAR University of Law in Hyderabad, and with Dr Vivekandan who by then had moved from Bangalore to Hyderabad. When Prof Ranbir Singh took up a new ViceChancellorship to start the National Law University, Delhi, two National Law Universities (NLUs) were involved, and NLUI Bangalore soon became the third. These partner NLUs supported AustLII's application to AusAID (Australia's foreign aid agency) for funding under its Public Sector Linkages Program (PSLP) to develop free access to law in South Asia, and funding of AUD 275,000 was eventually granted in late 2009. Database development started at AustLII, and the partners held their first meeting in New Delhi in January 2010. They were joined by Rajiv Gandhi School of Intellectual Property Law, Indian Institute of Technology - Kharagpur, where Dr Vivekandan was Dean for a time. They decided on the name and structure, and aimed to launch a new LII by early 2011.

Four other NLUs have become partners since 2010, bringing the total partners to eight: National University of Juridical Sciences (NUJS), Kolkata; Gujarat National Law University, Gandhinagar (GNLU); Tamil Nadu Dr Ambedkar Law University, Chennai (TNDALU); and Rajiv Gandhi National University of Law, Patiala (RGNUL). The March 2011 meeting of the partners decided to leave the partnership structure at eight members until formal incorporation, but to invite other law schools to become Supporting Organisations. Geographical dispersion of workload across India is seen as crucial to the long-term success of the project. National Law University, Delhi has hosted the two meetings of partners to date, but it is proposed that later meetings will be rotated between NLUs.

The Legal Information Institute of India (LII of India) < www.liiofindia.org $>$ aims to be an international standard, free-access and non-profit, comprehensive online collection of Indian legal information. The India technical hub of the project is at NALSAR, with Prof. Vivekanandan as Director, and technical staff yet to be employed. AustLII is providing the initial technical development, with progressive transfer of operations to the Indian partners planned for 2011 and 2012. AustLII's involvement is funded primarily by AusAID (Australia's foreign aid organisation),

Chung, "AustLII in 2010 - A Snapshot at Age 15", AustLII (Dec 2010), available at http://www.austlii.edu.au/austlii/publications/2010/1.pdf.

${ }^{45} \mathrm{http}: / /$ www.austlii.edu.au; AustLII receives over 650,000 page accesses per day, and has nearly 500 databases.

${ }^{46}$ WorldLII Legal Information Institute http://www.worldlii.org; Commonwealth Legal Information Institute http://www.commonlii.org; Asian Legal Information Institute http://www.asianlii.org 
but with additional funding (past and present) from the Australian Research Council (ARC).

\subsection{The Motivations of the Indian Partners}

For the Indian partners in this project, the development of free access to law in the Indian context is based on three important principles which they articulate in their public presentations, and which are consistent with the Free Access to Law Movement's "Declaration on Free Access to Law", 47 which they regard as a basic source of inspiration:

(1) Laws are by the people, for the people and of the people, and hence are the property of the society in general;

(2) The quality of democracy is directly proportional to people's awareness of, and access to the laws that govern their society; and

(3) If information, particularly legal information, is the oxygen of the body politic, it has to be breathed freely.

In short, free access to legal resources is expected to contribute toward combating misuse of power, corruption and policy deviations, leading to greater accountability and transparency in shaping healthy democracy, perhaps more than the tokenism of periodic elections that are often construed as democracy. If Indian democracy is to survive it will squarely depend on how a vigilant civil society functions, and this in turn requires free access to legal resources. Kofi Annan, the ex secretary General of the United Nations once remarked "If information and knowledge are central to democracy, they are the conditions for development". 48 A vibrant and dynamic society like India prides itself as an open society and its sustenance requires free access to the laws governing its citizens. The concept and construction of the LII of India is based on these principles, and the Indian law schools involved consider that they have the platform, visibility, and networking capability to make it a reality.

\subsection{The LII of India website and its launches}

LII of India is at the time of writing a year old and has been open for free access public use since 25 November 2010. LII of India was admitted as the thirty-forth member of the Free Access to Law Movement. ${ }^{49}$ The national launch of LII of India was organised and hosted by the National Law University, Delhi at the Vigyan Bhawan Conference Centre in Delhi on 9 March 2011. The launch was by Union Minister of Law and Justice, Dr M Veerappa Moily, and attended by members of the judiciary, law commissioners, and representatives of the foreign ministry and many agencies. It was followed by "satellite launches" in Hyderabad, Bangalore, and Kolkota during March and April 2011, hosted by the respective National Law Universities in those cities. The system and its contents are gradually becoming

\footnotetext{
47 Free Access to Law Movement, see note 43 above.

${ }^{48}$ See http://www.brainyquote.com/quotes/authors/k/kofi_annan.html.

49 "Members of the Free Access to Law Movement (FALM)", see note 42 above.
} 
known to lawyers, students, and librarians; as such awareness does not happen automatically.

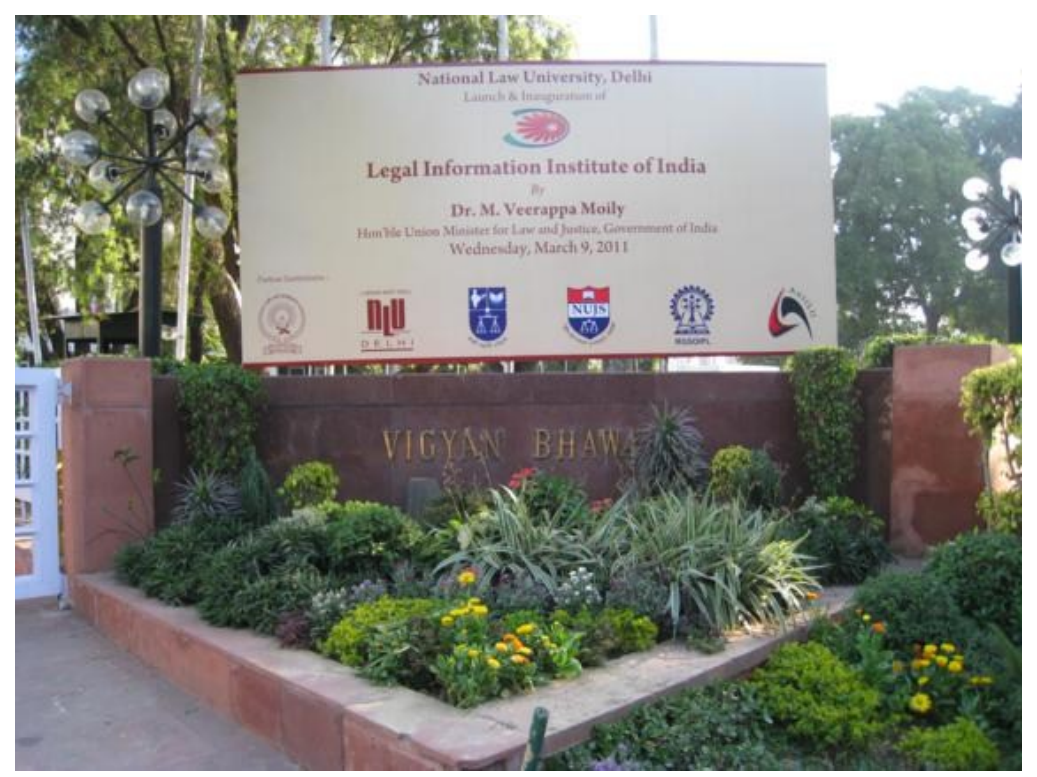

\section{Launch in New Delhi on 9 March 2011 at Vigyan Bhawan}

\subsection{Content Development: The "Five Pillars" in Stage One}

The initial version of LII of India is built largely on the shoulders of existing providers of legal information online, particularly India's National Informatics Centre (NIC), whose data collection efforts since the mid-1990s have resulted in dozens of separate case law and legislation databases. Several law schools, the External Affairs Ministry, and some supporting organisations like the Parliamentary Research Service (PRS), and iKanoon have also provided data. Virtual databases of Indian law developed from content on other LIIs cooperating with AustLII are also included. LII of India aggregates this content, puts it into a more consistent format, and makes it jointly searchable for the first time.

India's Copyright Act 1957 s52(q), like copyright laws in most countries, aids the non-government development of free access by exempting any reproduction of legislation, case law, law reform reports or similar official reports (in broad terms) from copyright infringement. ${ }^{50}$ Treaties are not mentioned, but the Indian government has no objection to reproduction of such treaties. ${ }^{51}$ Copyright law is therefore not an impediment to the development of LII of India or similar sites. Nor do Indian

\footnotetext{
${ }^{50}$ S 52 exempts from being an infringement of copyright: “(q) the reproduction or publication of-- (i) any matter which has been published in any Official Gazette except an Act of a Legislature ; (ii) any Act of a Legislature subject to the condition that such Act is reproduced or published together with any commentary thereon or any other original matter; (iii) the report of any committee, commission, council, board or other like body appointed by the Government if such report has been laid on the Table of the Legislature, unless the reproduction or publication of such report is prohibited by the Government; (iv) any judgment or order of a court, tribunal or other judicial authority, unless the reproduction or publication of such judgment or order is prohibited by the court, the tribunal or other judicial authority, as the case may be".

51 Personal communications with Indian Ministry of Foreign Affairs (Jan 2010) and subsequent development on LII of India of databases of Indian treaties without objection from the Ministry.
} 
government websites use the Robot Exclusion Protocol $^{52}$ to block other parties from using web robots or spiders from copying data from their sites.

By the time of the official launches of LII of India in March 2011, the first stage of development had resulted in 109 databases, and by the time of writing (1 December 2011) this had risen to 151 databases, plus four virtual databases where the data is drawn from databases located on other LIIs. However, an equally significant indicator of the size of what has been built is that LII of India now includes a total of 778,848 documents, with databases ranging in size from a few pieces of legislation from small states or territories, to the West Bengal Appellate Court database with over 100,000 documents.

The rate of expansion of content of LII of India is also accelerating. For example, in November 2011, 28,483 documents were added to the system. The main reason for the accelerated growth, and why it can be expected to be sustained, is that full automation has now been achieved for the updating of content from the six most prolific courts (Indian Supreme Court, Delhi High Court, Calcutta High Court, Calcutta Appellate Court, Calcutta High Court Port Blair Branch, and Information Commission of India). We expect that (provided funding is available), the system can continue to expand by over a quarter of a million documents per year for the indefinite future. It is already one of the largest LIIs, and may become the largest in due course.

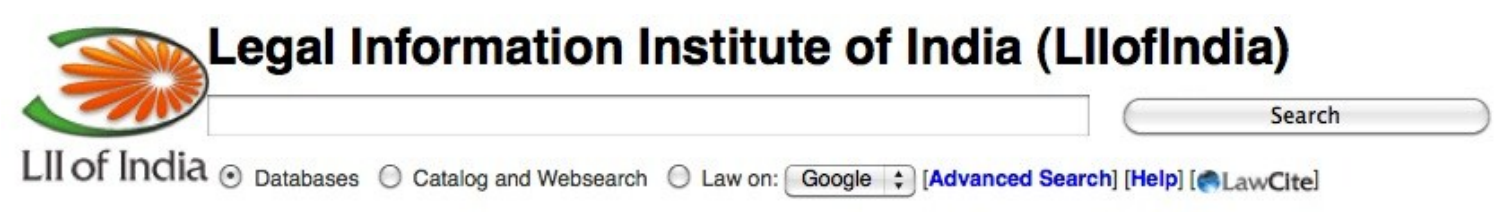

About Medla Releases Contact Copyright \& Usage Privacy Disclaimers Feedback Help

Free, independent and non-profit access to 151 databases of Indian law

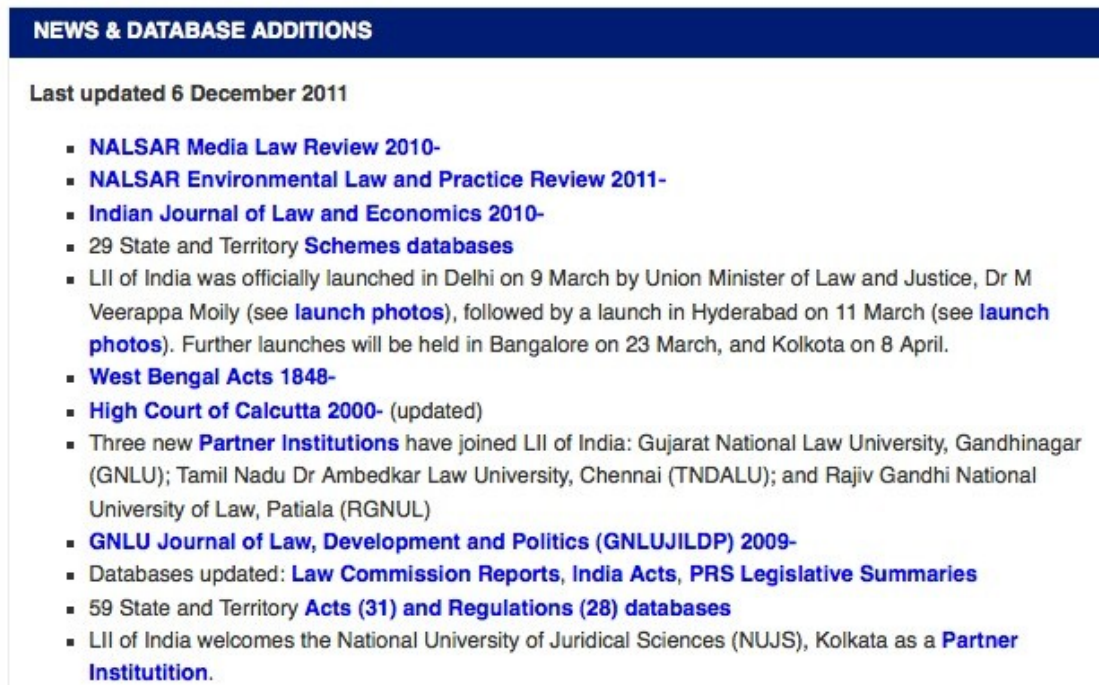

\section{CONTRIBUTORS}

Partner Institutions

Supporting Institutions

Funding Institutions

Contribute to Lllofindia

SPECIAL FEATURES \&

TOOLS

Declaration on Free

Access to Law

Brochure about Lllofindia

Quick guide to Lllofindia

\section{Top Front Page of LII of India, Showing Search Options and Recent Additions}

\footnotetext{
${ }^{52}$ See the Web Robots Page http://www.robotstxt.org/.
} 
The current content of LII of India and some of its limitations will now be outlined briefly, stating only at this point what content is included. Material which is still planned to be added under Stage 2 of content development is discussed later.

Legislation - There are ninety-three legislation-related databases with about 7,000 items of legislation: the India Code from 1836 (1248 acts); central government bills; the Constitution; acts from thirty-one states and territories (about 2,500 acts); regulations from twenty-eight states and territories (about 2,000); twenty-nine databases of "schemes" (other types of delegated regulations); commentary on central government acts (provided by the Parliamentary Research Service); and central government bills (recently again available from the Lok Sabha (Parliamentary) website). ${ }^{53}$

Case Law - There are forty-three databases of Indian case law comprising over 750,000 cases in full text: the Supreme Court from 1947; twenty-three high courts; nine district courts; six central government tribunals (those concerning electricity; railways; administrative decisions; right to information; cyber disputes; and IP); plus two virtual databases, one of cases concerning India from the pre-1873 English Reports (virtual database from CommonLII) and the other of cases concerning India in international courts and tribunals (virtual database from WorldLII).

Treaties - There are two databases: all Indian bilateral treaties to 1980, plus some subsequent bilateral treaties; plus a virtual database of Indian bilateral treaties found on other LIIs (from WorldLII and other LIIs).

Law Reform - Included so far are the eighty most recent reports of the Law Commission of India since $1999,{ }^{54}$ and the others are being added.

Scholarship - There are thirteen law journals included, ${ }^{55}$ eight of which are from the partner NLUs in LII of India (NUJS, NALSAR, GNLU and NLIU); plus one virtual database of articles about Indian law in other law journals (from other LIIs).

There is still considerable work to do on Stage One, primarily the extraction of case law from the remaining JUDIS databases, which will add another 200,000 decisions at least. But the phase of aggregation of existing web-sourced data from government resources is well underway (and complete for the largest courts and tribunals), subject to the continuing challenges of updating of databases. The different and more difficult tasks of sourcing data for Stage Two lie ahead.

\subsection{Design Considerations}

Design considerations in the development of LII of India included that the interface should be straight-forward but informative of the various search and browsing options

53

http://164.100.24.209/NewBios_search/Report3.aspx?house=bh\&typ=All\&year=2011\&sort=0\&stitle= bill.

54 http://www.liiofindia.org/in/other/lawreform/INLC/ .

${ }^{55}$ GNLU Journal of Law, Development and Politics, Indian Journal of Constitutional Law, Indian Journal of Intellectual Property Law, Indian Journal of Intellectual Property Rights, Indian Journal of Law and Economics, Indian Journal of Law and Technology, ISIL Year Book of International Humanitarian and Refugee Law, NALSAR Environmental Law and Practice Review, NALSAR Law Review, NALSAR Media Law Review, NALSAR Student Law Review, and NUJS Law Review. 
that the complexity of the Indian legal system makes necessary. It needed to enable the data to be searched over the whole system simultaneously, or over only a particular type of data (e.g. case law), or for only a specific state or territory. Because the quantities of data to be searched are so large, fast search speed is essential. Finally, the nature of the Indian legal system makes it acceptable to start with a system that is based on English, for reasons already indicated and discussed in more detail later.

As can be seen from the first line of the front page extract below, each of the "five pillars" of content types described above can be separately searched or browsed. However, what is more important is that each state's or territory's databases can be searched separately, with the case law, Acts, regulations, and other relevant databases for the state or territory all being able to be searched together. This is not possible on any of the government-provided sites. In Stage One, this is often limited to the high court decisions for a state, its acts, and its regulations (to the extent that each of these is available online). In some cases there is also a district court, and occasionally a law journal from a NLU located in the state. This is illustrated later in relation to West Bengal. As can be seen from the screen extract below, the facility is available for all thirty-six states and territories.

Cases | Legislation | Journals and Scholarship | Law Reform | Treaties

\begin{tabular}{|l|}
\hline ALL DATABASES \\
\hline CENTRAL GOVERNMENT \\
\hline Supreme Court \\
\hline Indian Code \\
\hline More... \\
\hline STATES \\
\hline Andhra Pradesh \\
\hline Arunachal Pradesh \\
\hline Assam \\
\hline Bihar \\
\hline Chhattisgarh \\
\hline Goa \\
\hline
\end{tabular}

\begin{tabular}{|l|}
\hline DATABASES - STATES \\
\hline Gujarat \\
\hline Haryana \\
\hline Himachal Pradesh \\
\hline Jammu and Kashmir \\
\hline Jharkhand \\
\hline Karnataka \\
\hline Kerala \\
\hline Madhya Pradesh \\
\hline Maharashtra \\
\hline Manipur \\
\hline Meghalaya \\
\hline
\end{tabular}

\begin{tabular}{|l|}
\hline DATABASES - STATES \\
\hline Mizoram \\
\hline Nagaland \\
\hline Orissa \\
\hline Punjab \\
\hline Rajasthan \\
\hline Sikkim \\
\hline Tamil Nadu \\
Tripura \\
\hline Uttar Pradesh \\
\hline Uttarakhand \\
\hline West Bengal \\
\hline
\end{tabular}

\begin{tabular}{|l}
\hline DATABASES - TERRITORIES \\
\hline UNION TERRITORIES \\
Andaman and Nicobar \\
Islands \\
Chandigarh \\
Dadra and Nagar Havell \\
Daman and Diu \\
Delhi - National Capital \\
\hline Lakshadweep \\
Puducherry \\
\hline CATALOG \\
\hline All Categorles \\
\hline By Subject
\end{tabular}

\section{Extract from Front Page of LII of India, Showing Access to Databases by Type, and by State and Territory}

Stage One has also incorporated a number of features found on other LIIs developed by AustLII, including a catalogue of hundreds of Indian law-related websites ${ }^{56}$ (also categorised by state and territory, as illustrated below), and a "Law on Google" feature which translates LII of India searches into Google syntax, and limits their scope to legal materials from India (and where appropriate to a specific state or

\footnotetext{
56 The top-level India page of the catalogue is at http://www.worldlii.org/catalog/221.html.
} 
territory). LII of India therefore offers as many different ways to find free access online legal information, whether in its own databases or not, as can be provided.

Another design consideration is that LII of India's content should also be searchable from the other free access to law portals, CommonLII, AsianLII, and WorldLII. ${ }^{57}$ Users who find LII of India content through searches over these portals are returned to LII of India to view the content. The file structure of LII of India has been organised in a similar way to the file structure of these portals, so as to make it much easier to include this content in their searches.

\subsection{Technical Facilities}

LII of India is using the AustLII-developed open source Sino search engine ${ }^{58}$ and other AustLII-developed tools on a Linux platform. The search engine, used by other LIIs, ${ }^{59}$ enables Boolean and proximity searching; gives flexible displays of results (by relevance, by date, by database and by citation frequency). LII of India has relatively consistent formatting of data across Indian jurisdictions, insofar as the source data permits; large scale automated addition of hypertext links among cases, legislation, treaties, law journal articles and law reform reports; and provision of "noteups" from texts to where they are cited. ${ }^{60}$

LII of India also has automated extraction of parallel citations and creation of citation tables by the AustLII-developed LawCite citatory, ${ }^{61}$ which includes citation data drawn from the twelve LIIs collaborating in WorldLII, resulting in citation records for approximately four million cases, journal articles and treaties. The LawCite international citator is also integrated into the search results of LII of India, showing the subsequent citation histories (in India and overseas) of 496,000 Indian cases law journal articles and treaties. More citation data will be extracted in due course, once further work is done on the automated recognition of unique India patterns of case law citations, and on how use can be made of them in a variety of document formats. An example of LawCite as an international citator is the Indian Supreme Court decision in Indian Express Newspapers Bombay (P) Ltd v Union of India [1984] INSC 230; (1985) 2 SCR 287; (1985) 1 SCC 641; [1985] SCC (Tax) 121; 19842 SCALE 853, which the LawCite record shows has been cited sixty-seven times, including by courts in Lesotho and South Africa, as well as by numerous Indian courts.

At present the LII of India server is located at AustLII. A staged transfer of processing control between production servers and mirror servers, in Australia and India, will start once an AusAID-funded mirror server is acquired and installed in Hyderabad, and technical staff are employed there. Scanning, comprehensiveness checking, content acquisition and other labour-intensive tasks will be distributed geographically

\footnotetext{
${ }^{57}$ See addresses in earlier footnote.

${ }^{58}$ Available from the Sino directory http://www.austlii.edu.au/techlib/software/sino/.

${ }^{59}$ Namely AsianLII, AustLII, BAILII, CommonLII, CyLaw, HKLII, LiberLII, NZLII, PacLII, SAFLII and WorldLII; full names and web addresses of all these LIIs are at http://www.fatlm.org/.

60 See details of search and navigation functions in Quick Guide to LII of India http:/liiofindia.org/liiofindia/guide/current.pdf.

61 See http://www.austlii.edu.au/cgi-dev/lawcite.pl?juris=india (at the top of the LII of India front page) for all Indian cases available through LawCite.
} 
among the partner and supporting law schools in India, with an initial distribution of responsibilities having been agreed at the March 2011 meeting of partner law schools.

\subsection{Usage}

By December 2011 the LII of India website is receiving over 6,000 page requests per day, and will have received approximately 2.25 million accesses in the 2011 calendar year. This is a respectable result for the first year while databases are still developing, but is only a fraction of the expected long-term usage rate. Because search engine web spiders are blocked from accessing any case law databases (over 95\% of all files), almost all of these accesses are by real users, not by search engines spiders.

As might be expected, the most-accessed case law databases were those of the central government courts and tribunals (67,000 accesses per month) and West Bengal courts (11,000 accesses per month). For legislation databases the most accesses were to central government legislation $(9,000$ accesses per month) and West Bengal legislation (500 accesses per month). The significant usage of West Bengal databases reflects the quantity and quality of the content available from one state on which we are focussing initial development efforts. The small collection of law journals receives 2,500 accesses per month, and the law reform reports and treaties receive about half that usage.

It is impossible to establish the percentages of this usage which comes from Indian users, because $88 \%$ of all accesses come from numerical IP addresses which cannot be resolved into domain names (e.g. with the ".in" suffix), due to incomplete server configuration. Of the $12 \%$ of usage which does come from geographically identifiable addresses, usage from India and Australia are each about ten times larger than from any other country. It seems reasonable to infer (or at least, to speculate) that the majority of LII of India usage comes from India, from incompletely configured servers, but the precise percentages must remain undetermined. There is also significant identifiable usage (at least $10 \%$ of the Indian identifiable usage) originating from the UK, USA, Malaysia, Canada, South Africa, and Pakistan, as well as from Australia.

In summary, the usage is modest but satisfactory, the most popular databases are those with the largest amount of content, and the locations of users seem to be mainly from India but with significant international usage as well.

\section{Future plans and challenges}

The future of LII of India depends on a number of factors, including the establishment of an effective technical team and servers in India, an Indian-based governance structure, collaboration with organisations in India with similar goals, establishment of local financial sustainability, and continuing technical support from AustLII during the establishment phase. While these elements of long-term sustainability are being achieved, stage two of content development continues.

\subsection{Content Development: Stage Two}

The second stage of content development, now beginning, involves as its key focus the capture of additional case law and legislation not already digitised, from all thirtysix jurisdictions, and from sources spanning jurisdictions. This is a huge task, 
requiring a decentralised data collection approach. In additional to the five initial Indian partners, other supporting and collaborating institutions are being sought, primarily in the academic sector, to give as broad an "ownership" of LII of India as possible, and so as to decentralise the difficult task of obtaining data at the state and territory levels.

Take the State of West Bengal as an example of what needs to be done in a single state. West Bengal was home to the world's first and most long-lived elected Marxist government. The Bengal Presidency, based in Calcutta (now Kolkota), was also one of the origins of common law courts in India (with the Madras and Delhi Presidencies). The West Bengal home page at present includes three databases. The High Court of Calcutta, High Court of Calcutta (Appellate) and High Court of Calcutta (Port Blair Bench) databases between them contain over 200,000 decisions since 2000. The West Bengal Acts database contains 364 items of legislation from 1848 to 1984 (provided by PRS Laws of India), and a few subsequent acts. The West Bengal page also includes the law journal of the National Institute of Juridical Science (NUJS), Kolkota. NUJS has also agreed to develop an "NUJS Law Research Series" database, a repository for all legal scholarship from one of India's leading NLUs. Much is still to be done before this is as valuable as possible a research facility for West Bengal law. NUJS has agreed to test the comprehensiveness of the three West Bengal High Court databases against a list of the 100 most significant cases in West Bengal law from the last decade, to assess whether they are all included in the databases (or what is the percentage of inclusion). To improve the legislation, NUJS has provided the West Bengal Code to 2003 (10 volumes) to AustLII to scan and OCR, and the annual volumes of legislation since 2003. The databases created from this legislation will then be provided to PRS Legislative Research for use on their Laws of India service ${ }^{62}$ if they wish, as well as being made available on LII of India.

\footnotetext{
${ }^{62}$ Laws of India at http://www.lawsofindia.org/index.php.
} 


\section{West Bengal}

You are here: Llloflndia $\gg$ Resources $\gg$ West Bengal

Search [Search Help] [Advanced Search]

Search: $\odot$ Databases $\odot$ Catalog \& Websearch $\odot$ Law on Google

\section{Databases}

- High Court of Calcutta 2009(Llloflndia)

- High Court of Calcutta Port Blair

Bench 2008- (Llloflndia)
- High Court of Calcutta (Appellate

Side) 2003- (LIloflndia)

- West Bengal Acts (Lllofindia)

- NUJS Law Review 2008- (LIlofIndia)

\section{Catalog and Websearch}

- Courts \& Case-Law

- Government

- Legislation
- Education

- Lawyers

- Paliament

\section{West Bengal Home Page with Search Options, Databases, and Catalogue}

Across India as a whole, Stage Two development requires further work on each of the "five pillars" of free access, and much of it will require the work and cooperation of partner and supporting law schools in the relevant states:

- Legislation - Missing as yet are the majority of annual acts from states, most consolidated acts (central or from states), and bills from states. Discussions are ongoing with PRS Legislative Research concerning comprehensive cooperation in relation to provision of free access Indian legislation from all jurisdictions. The digitisation of printed statutes from selected priority states, commencing with West Bengal, will indicate what demand there is for this information.

- Case law - Case law from important state inferior courts and tribunals needs to be obtained. The comprehensiveness of the high court database for each state needs to be checked. As soon as possible, active cooperation with NIC/JUDIS is necessary so that a direct email feed of case law (if possible) is provided in replacement of the current very inefficient and costly methods of extracting data from form-based court websites.

- Treaties - Paper or soft copies of missing post-1980 bilateral treaties need to be obtained from the Ministry of External Affairs, and digitised where necessary. This may require cooperation from the Indian Society of International Law (ISIL).

- Law reform - The first 156 reports of the Law Commission of India are still to be added, but this is underway as part of completion of Stage One. Reports of state law reform bodies need to be obtained and digitised where they are not already in digital form. Reports from important central government bodies such as the National Human Rights Commission also need to be added. 
- Legal Scholarship - The law journals from as many Indian law schools as possible need to be obtained and digitised, from both partner law schools and those others wishing to provide their journals. All partner law schools, and then other law schools, need to be encouraged to provide scholarship repositories ("Law Research Series"). The cooperation of the Indian Law Institute in providing its journal and yearbook ("Annual Review") for free access needs to be sought.

Identification of a Stage Two invites the question of what would be in a Stage Three. One aspect is that most LIIs have started with a focus on current law, and LII of India is no exception, with the decisions of most high courts only going back a decade or so. The digitisation or other acquisition of India's rich history of development of the common law would be a valuable task once more immediate priorities are resolved. So would the provision of consolidated legislation where it is not yet available.

\subsection{Collaboration}

Seeking cooperation with all those involved in the provision of free access to Indian law will probably be the key to the successful development of LII of India, because the task of capturing all the relevant data is too large for any one organisation. The very extensive IndianKanoon ${ }^{63}$ (iKanoon) search engine for Indian case law is sharing its case law with LII of India (content is still being processed from its collection), and LII of India has offered to do likewise with those databases iKanoon does not hold. Cross-use of data extraction software is also being considered. Senior personnel from PRS, and iKanoon have agreed to join an LII of India Technical Advisory Committee ${ }^{64}$ once LII of India has its own technical staff.

The other key element of cooperation is of course that provided by the NLU (national law university) partners in LII of India, and NLUs and other law schools who wish to support this development in their states. The commitments made by NUJS in relation to development of the West Bengal databases are a model which now needs to be successfully applied to law schools willing to cover all other states and territories. It will be a long process, but it should ultimately give India a sustainable LII.

\subsection{Languages other than English}

As explained earlier, English has a unique position as an "associate" official language in India's law and constitution, and continues to be widely spoken in both north and south to an extent matched by no indigenous language. English continues to be the language of most legislation in India, though some state and territory legislation is in local languages. All bills, acts and regulations, of both the centre and the states and territories, must be in English unless legislation of the Indian Parliament provides otherwise. ${ }^{65}$ Where a state legislature does prescribe local languages for legislation, an English language translation published in the Official Gazette of the state is

\footnotetext{
${ }^{63}$ IKanoon at http://www.indiankanoon.org/.

${ }^{64}$ Chakshu Roy from PRS and Sushant Sinha from iKanoon.

${ }^{65}$ Indian Constitution, Art 348(1).
} 
deemed to also be an authoritative text. ${ }^{66}$ The India Code is available in Hindi. Languages other than English may be used in proceedings of the high courts of a state or territory (but not in the judgments or orders of such courts), by agreement of both the governor of a state, and the President of India, in accordance with constitutional requirements. ${ }^{67}$ Judgments of lower courts may be in languages other than English. The use of Hindi has been approved in various state courts. There are proposals that Tamil should be the official court language in the Madras High Court. ${ }^{68}$ Where legislation or orders made under it are available in translation from English (or viceversa), the Copyright Act 1957, s52(r) also allows liberal use of such translations by republishers such as LII of India. ${ }^{69}$

It is sufficient to say that Indian legislation, court decisions (at least of lower courts), and other public legal information, are likely to be available increasingly in languages other than English in future. While the position of English in India's legal system is protected very strongly in Indian law, the Indian legal system is likely to gradually become more multi-lingual. English is also only spoken by a minority of people in India. For both reasons, it will be necessary at some point in the further development for LII of India to aim to incorporate legal documents in other Indian national languages. This requirement introduces technical complexities, because Indian languages require the use of double-byte representations, and cannot be searched in the same way as the Roman alphabet used by English which employs a single-byte representation. However, AustLII's Sino search engine, used by LII of India, has a multi-lingual search capacity allowing simultaneous searching and ranking of documents in languages with different representations. As yet, this capacity has only been employed for the simultaneous searching of English and Chinese, for the Hong Kong Legal Information Institute and the Asian Legal Information Institute. ${ }^{70}$ It should be possible to develop this capacity so that LII of India can simultaneously search and rank documents in English and Indian languages.

\footnotetext{
${ }^{66}$ Indian Constitution, Art 348(3).

${ }^{67}$ Art 348(2) of the Constitution provides that “...the Governor of a State may, with the previous consent of the President, authorise the use of the Hindi language, or any other language used for any official purposes of the State, in proceedings in the High Court having its principal seat in that State: Provided that nothing in this clause shall apply to any judgment, decree or order passed or made by such High Court".

68 "Indian Law: Tamil as Language in Courts", available at http://www.lawisgreek.com/indian-lawtamil-as-language-in-courts.

${ }^{69}$ S 52 exempts from being an infringement of copyright: "(r) the production or publication of a translation in any Indian language of an Act of a Legislature and of any rules or orders made thereunder- (i) if no translation of such Act or rules or orders in that language has previously been produced or published by the Government; or (ii)where a translation of such Act or rules or orders in that language has been produced or published by the Government, if the translation is not available for sale to the public: Provided that such translation contains a statement at a prominent place to the effect that the translation has not been authorised or accepted as authentic by the Government".

${ }^{70}$ A Fung, K Pun, and P Chung, "Searching in Chinese: The Experience of HKLII", Proceedings of the Law via Internet Conference, University of Hong Kong, June 2011.
} 


\subsection{Sustainability and Governance}

A trust, charitable company or other appropriate entity will be formed to provide the governance structure for LII of India, with assistance from an Advisory Committee. There is now an Interim Management Committee comprising representatives of the partner Law Schools and AustLII. The AusAID project is an appropriate management vehicle for the project while AusAID funding of the project continues, but a more permanent structure will then be needed.

Establishing financial sustainability from local funding sources is crucial, as an Indian system is not likely to obtain ongoing foreign aid funding. A central government start-up grant is possible, and is being pursued. Funding solely from the legal profession is considered by the Indian partners not to be feasible in India, though it may be possible to obtain some level of contributions. One funding model under consideration involves soliciting voluntary contributions from a diverse range of contributors including governments and academic sources using the model employed by AustLII. ${ }^{71}$

A third element of sustainability is that AustLII intends to continue providing technical assistance to LII of India for so long as it is requested (subject to AustLII's own capacity to do so), irrespective of the availability of funding assistance. AustLII continues to provide such assistance other LIIs that it has assisted to develop, in keeping with the cooperative aspirations of the Declaration on Free Access to Law.

\section{Conclusions}

Beyond the questions of whether the LII of India will prove to be valuable to India's lawyers, students, businesses, administrators, and citizens at large, we should ask some broader questions to conclude. Might this India experiment be valuable as a model for creating free access to legal information in some other equally complex countries? And what is the significance of free access to legal information (no matter who provides it) for India's vibrant democracy?

\subsection{A Model for Assisting LII Development?}

There are many ways in which established LIIs can assist in the development of new LIIs, in order to further the global spread of free access to legal information and the objectives of the Free Access to Law Movement. Although the development of LII of India is far from complete, it may demonstrate key elements of one model for successful LII development, such as the following:

- Early identification by an established LII of local partner organisations with substantial non-commercial reasons to wish to establish free access to law, and their involvement in all stages of the project.

- Adoption of a broad approach to content acquisition, including all "five pillars" of free access content, so as to create a LII with the richest possible search results and serving the broadest audience.

\footnotetext{
${ }^{71}$ See AustLII 2011 Funding Sources, available at http://www.austlii.edu.au/austlii/sponsors/.
} 
- Utilisation of available online resources to build an initial system quickly, with impact.

- Active collaboration by local partners to source data previously not available online.

- Active collaboration with other free access to law providers, particularly from the NGO sector, including swapping and sharing of database content.

- Continuation involvement by the established LII in technical assistance, and possibly in governance.

- Development of a funding model relying on diverse sources of funding.

The tentative view of all the partners involved in the development of LII of India is that this approach is paying dividends for India, though there is much work to be done before it can be demonstrated that the model has been successful and sustainable.

\subsection{A Necessary Element in India's "Monitory Democracy"?}

If India is a pioneer of the notion of "monitory democracy", then one of the key mechanisms of accountability of government decision-making must be open access to government information. Without guaranteed access to information about what government does, extra-parliamentary institutions have no possibility of making government's accountable. The enormous success of the right to information movement in India over the last decade is therefore crucial to its monitory democracy. Surprisingly, this is not explicitly recognised as a key element in Keane's account either of monitory democracy generally or of the Indian example.

It is part and parcel of this argument to say that an essential element of any monitory democracy must be that citizens have effective and up-to-date access to the laws that govern both them, and (in a society based on the rule of law) also govern the powerful institutions of society in both the public and private sectors. For NGOs representing citizens or criticising governments or polluters, for small businesses wanting to assert their rights against cartels or unfair competitors, or for lawyers without the assets of national or multi-national law firms wanting to defend their clients against abuses of power, such access to legal information is essential to enable their roles in making the institutions of monitory democracy work as they are designed. Both India's public institutions that provide a basic form of such access, and the Legal Information Institute of India and similar NGOs adding value to that legal information, are playing an essential role in India's emerging monitory democracy. 